\title{
Globalization - its influences \& impacts on specific regions of Africa
}

\author{
Monika Nova ${ }^{1,2, *}$ \\ ${ }^{1}$ Charles University, Institute of Legal History, nám. Curieových 901/7, 11640 Prague, Czech republic \\ ${ }^{2}$ Charles University, Department of Psychosocial Sciences and Ethics, Pacovská 4, 14021 Prague, \\ Czech republic
}

\begin{abstract}
Relying on her own practical experience, the author presents the possible ways of opening up job opportunities in some selected regions of developing countries in Africa. The paper will thus cover both merits and demerits of globalization encountered in the countries' economies and in their social \& cultural spheres. Applying previous experience, the text aims to provide theoretical summary of the globalization process and its consequences for the continent. In addition, it highlights the causal relation between unemployment and migration, and shows the disruptive influence that globalization has on the local markets and social \& cultural life. In the empirical section of the paper the author submits results of her own combined research that employed both quantitative and qualitative methods. The research, conducted in Uganda.
\end{abstract}

\section{Introduction}

Resorting to a little hyperbole, Tomáš Halík [1], said that globalization has been triggered by Jesus' sentence: "Go therefore and make disciples of all the nations" (American Standard) [Go ye therefore, and teach all nations (King James)]. G. Therbron [2], a British sociologist, puts the first wave of globalization to the 4th through 7th centuries when the major world religions began to spread. Pointing and Wallenstein [2,3], see the phenomenon associated with colonization and the early stages of modern capitalism, i.e. the turn of the 16th century. Giddens statement that globalization has been kicked off by the modernist tendencies in the 18th century and Perlmutter [4], maintains that the process was not initiated before the East and West settled their conflict. The author reflects theoretical and empirical scientific works by the authors: Macik-Frey, M., Quick, J. C., Nelson, D. L. [5] Lehdonvirta, V., Kässi, O., Hjorth, I., Barnard, H., \& Graham, M. [6] Shane, S., Venkataraman, S., \& MacMillan, I. [7] Keupp, M. M., \& Gassmann, O. [8] Stelios M., Papaioannou, E. [9] Shaohua Ch., Ravallion, M. [10] Caicedo, V., F. [11].

\footnotetext{
*Corresponding author: monika.nova@htf.cuni.cz
} 


\subsection{Economic globalization}

The economic globalization is characterized by world markets tied in a single system and national economics included in a global economic framework. Players of paramount importance in the phenomenon are supranational companies capable of operating in a multitude of countries and states. This type of globalization is also driven by venture capital flowing freely between global stock markets, affecting world currencies and the markets themselves. Different sectors of global economy experience the concentration of decisionmaking, but also the growth of work productivity. Newly emerging market players intensify competition... The last decade has been typical of steep rise in international commerce, even steeper rise in direct foreign investments and the steepest of all - the growth observed in the volume of international monetary transactions. Nowadays, as the paper's author (Nova) statement, the economic globalization is of special importance because the unemployment is still a huge problem, and in seeking a solution to it the migration of African population can be a consideration. Nowadays, the economic development of every country and its competitiveness on the world market is supported by the creation of innovation (knowledgebased economy), especially from an Industry 4.0 point of view [12].

\subsection{Social globalization}

The social globalization manifests itself in the emergence of links newly developed between societies and people generally. Mass public transportation facilitates travelling, boosts tourism and encourages international migration. Modern media, communication technologies and especially the Internet make information exchange instantaneous and widely accessible. The social dimension of globalization refers to the impact of globalization on the life and work of people, on their families, and their societies [13]. Discussing these new developments, people speak about the "space-time shrinking of the world", "virtual communities" and the "global village". The author of this paper has observed that persons living in different regions of Africa enjoy access to information and particularly to the contemporary means of mobility in very different degrees - this separation from resources and technologies widens not only the information gap, but mainly the social gap.

\subsection{Cultural globalization}

The cultural globalization intensifies contacts among cultures, spreads cultural phenomena and supports cross-cultural exchange. Such contacts and exchanges then affect all cultures and societies of the world and spawn new, hybrid forms. It is true that the cultures have never been quite separated and have always influenced each other and adjusted themselves to each other. In contrast to the past, however, only now they are exposed to close global interrelations and this exposition occasionally results in radical and sometimes even violent forms of rejecting globalization observed around the entire world. We may then witness the emergence and strengthening of national and ethnic identities, specific lifestyles and living in community bubbles. Aware of the facts mentioned above, the paper's author maintains that these phenomena are typical of the "richer" or "western" countries, whereas the developing and therefore poorer countries strive to catch up with the richer western countries by emulating their fashion while damaging their own culture by suppressing ethnic languages and cultural identity as such.

\subsection{Political globalization}

The political globalization is characterized by the tight integration and interconnection of individual states and countries; by the influential position of international entities (UN, EN, NATO, ...); and by the impact of politically weighty institutions like the International 
Monetary Fund, World Bank and/or the World Trade Organization. The process of deciding about a host of momentous affairs is thus taken away from the state and shifted onto another level. Even today politicians, experts and the world public differ in opinions about the extent to which the globalization deprives different countries of their sovereignty, now partially vested in supranational political institutions (UN, European Union, etc.).

The paper's author believes that certain political rights actually have moved outside the borders of individual states (such as the international treaties on genocide, torture, rights of children) and the role of global political institutions has thus been generally enhanced. Moreover, the author asserts that the process of political globalization covers also the activities of non-governmental organizations pursued worldwide, and nowadays especially important in providing much-needed education, assistance and social \& healthcare services. Specific adverse consequences of globalization have been roundly criticized by a range of civil movements which oppose, for example, socially irresponsible conduct of international financial institutions and supranational corporations.

\subsection{Environmental globalization}

The environmental globalization follows from the simple fact that the Earth is a single selfsustaining ecosystem and mankind has no other. Oceans, forests and the diversity of plant and animal species can be considered, together with climate conditions, global public property. No matter how patchy is the damage done to environment, its detrimental effect on the vital functions of the global ecosystem shall be felt by the entire Earth population. More often than not, the expenses needed to remedy damaged environment are not reflected in the market prices of goods and services - that is why they are not paid by consumers but by the locals, or possibly they are passed down to the future generations. A problem of its own is posed by the emissions of so-called greenhouse gases (primarily the carbon dioxide) believed to contribute to global warming. The main burden of the trouble shall be borne first and foremost by the population of the least developed countries which can least be blamed for the climate changes.

\section{Globalization in Africa}

Given that African countries entered the world economy already before the second industrial revolution (during which the European industries generated growing demand for raw materials and labor), the Africa's inclusion in globalization is hardly a recent phenomenon. At that time African natives were moved to Latin America, North America and Europe so as to supply labor for their thriving industries. In the process Africa lost about 20 million people of working age - a development that plunged the continent into economic downturn for years. [14] The second wave of globalization in Africa took on the form of colonization wherein one country dominated both political and economic affairs of other countries. Conference held 1884 to 1885 in Berlin split Africa into sections distributed among European powers, with the largest chunks governed by Great Britain and France (before WWI 3pprox.. 2/3 of the territory and after as much as $70 \%$ of the continent). With the war over, only $7 \%$ of the land remained uncolonized. [15] The locals were intentionally kept economically undeveloped and uneducated (during the 1940s thirty million native inhabitants of Nigeria produced only 150 domestic lawyers and 160 physicians). A defining moment of decolonization came in 1941 - the year witnessed the drawing of Atlantic Charter in which the nations were granted, inter alia, the right of self-determination. [16]. 


\subsection{Positive and negative consequences of globalization in Africa}

The benefits and drawbacks of globalization are felt in four areas: economic, technological, social \& political and cultural. Modern technologies (e.g. prompt and simple international bank transactions) along with cheaper and easily accessible transportation stimulated the growth of international trade. Some theories suggest that the international trade and direct cross-border investments are just methods applied to exploit the unskilled labor still available in the developing countries. [17] Other theories hold that the international trade (i.e. opening up new markets, removing commercial barriers and giving local businessmen a chance of exporting) offers opportunities facilitating development and accelerating economic growth. The direct foreign investments can then give impetus to local science and research. Technical progress, as represented by state-of-the-art communication technologies, is a crucial factor of global connectivity, joining both countries and individuals. The world thus turns into a "global village". Users of mobile (or cell...) phones working abroad can transfer money to their relatives through what is termed the M-payments. This concept proved to be an immense success in Uganda, but no less in Tanzania and Kenya. Mobile phones, and the hotlines that can be accessed with them, can be employed to report criminal assaults (in Kenya and Tanzania). As regards the Internet connectivity, in 2017 about 1.4 billion Africans were on line using the Internet services. [18] Other incontestably beneficial consequences of political globalization are better education and successful suppression of organized crime. A multitude of theories claim however that globalization encourages illegal drug trafficking and human trafficking - problems also aggravated by migration. In consequence, a globalized political system can result in a clash of ideologies. Countries of the world differ substantially in their well-established political ideologies as diverse as communism and democracy. The developing countries typically embrace an ideology which offers more benefits at the cost of less risks. Their own will is thus (once again) defeated and their sovereignty compromised. This happens particularly in countries governed by dictators or long-term presidents [19].

\section{Empirical section}

The subject of the paper was chosen on the strength of the author's long engagement in developmental cooperation and in providing international humanitarian aid. The choice was also inspired by her intimate familiarity with the area to be researched. The author's interest in the chosen subject was aroused by her professional experience and then further molded by her practical knowledge of Ugandan health \& social system and its workings.

\subsection{Target and methodology}

The research section explored primarily a random sample of respondents selected from a site in south-eastern Uganda. The research itself covered villages erected without any infrastructure, about $100 \mathrm{~km}$ away from the nearest larger town. In addition, we sought the opinions of local salesmen on the consequences that globalization had for their business (they sold mainly Chinese goods: household amenities, shoes, clothes, toys plus globally available drinks and foodstuffs). The nature of the chosen subject required that the research apply both qualitative and quantitative methods.

\subsection{Methods and methodology}

Our research relied on a variety of data sources. The sample to be researched was split into two groups: population versus buyers and population versus sellers.

Principle techniques:The first technique was an on-site questionnaire research. Respondents were chosen at random from the locals aged 18 and above. The survey 
encompassed the districts of Kisoro, Kabale and Ntungamo in south-eastern Uganda, covering the sites that the author had a chance of exploring personally in her long-time work for an NGO. The questionnaire treated several topics cast into questions. The questions were inspired by focus groups formed from salesmen - local and Chinese. Moreover, the focus group included also representatives of foreign NGOs from the Czech Republic, Ireland and France who were involved in developmental projects and programs under way on the site of our interest.

This qualitative research covered 339 respondents, out of which 306 returned the questionnaires fully filled in and ready for subsequent processing. The second technique was an interview conducted with the heads of CR, Irish and French NGOs. This method was dependent on opinions expressed in answers to our pre-defined research question. Besides, the interview helped us form an overall opinion on the subject in hand, assisted by people who had long-term lived on the site, worked with the locals and been engaged in developmental programs. The third technique rested in organizing a focus group with local salesmen. This technique was also instrumental in triangulation through which we tried to achieve a deeper understanding of the questionnaire results. Together with Goldman [20] we believe that "focus groups provide a profusion of information whose quality differs from what can be obtained through individual interviews". We have found this activity extremely time consuming, since it did not require just a mechanical speech-to-text transfer but needed cherry-picking of the most important items of information. The results of the quantitative survey were treated first, followed by those of the qualitative method. This sequence of processing results is justified particularly by the fact that while the quantitative method is focused generally on typical and/or frequent occurrences, the qualitative approach aims deeper, trying to reveal the causes of findings and observations. Put otherwise, the qualitative research results assisted us in partially deepening and better understanding what was found in the quantitative research. In addition, they were instrumental in recording some momentous circumstances and processes related to the quantitative results.

\subsection{Research problem, target and question. Hypotheses.}

Research problem is defined as the impact that globalization has in African rural areas on the relation between local goods and goods imported from abroad. Research target is defined as the mapping of current situation now encountered in the south-eastern Uganda, the District of Tunagamo. Specifically, the area comprises several villages with about 20 thousand inhabitants altogether. Research question - "What is the role played by the local goods sold by the local tradespeople as opposed to the ever-growing offer of imported products?"

Hypotheses: Hypothesis 1: „The locals prefer Asian articles of garment over clothes produced by local dressmakers. "Hypothesis 1: has been proven true. Hypothesis 2: „The locals prefer Asian shoes of plastic over hand-made shoes produced by local shoemakers". Hypothesis 2: has been proven true. Hypothesis 3: „The buyers attach more weight to the price of a product than to its domestic or foreign provenance. "Hypothesis 3: has been proven true. Hypothesis 4: „The locals able to access the Internet and social networks would like to have their shopping delivered to their homes. "Hypothesis 4: has been proven false. Hypothesis 5: „When deciding on a purchase, the locals are influenced by advertising on TV and/or spread through social services." Hypothesis 5: has been proven true.

\section{Discussion}

Our research revealed opinions and mindsets of not just buyers but also their counterparts, i.e. local sales persons. The research demonstrated that the buying habits of people were greatly affected by media, social networks and by the better quality of imported goods. As 
regards prices, the imported goods (primarily from Asia) are kept competitive with local products, and may even be somewhat cheaper. Two recent years have seen the owners of permanent (or stone...) shops starting to reduce the assortment purchased from local suppliers, and a similar trend can be identified in marketplaces. Tailors, dressmakers, shoemakers, manufacturers of toys and wicker baskets are unanimous in believing that the oversupply of cheaper goods from abroad may price their products out of the local market. The most valuable conclusion of the paper in its author's eyes is the expansion of social enterprise recommended as a part of developmental assistance.

Sellers affected by the decline of demand do not generate profit and, if they cannot be requalified, they lose their gainful occupation. In consequence, they and their families sink into poverty and face also other hardships (e.g. they cannot support school attendance of all their kids; the family cannot afford the bare essentials for existence; etc...). All these facts (poverty, unemployment, diminishing of profits) were mentioned by our respondents as reasons for their meditating migration - not only abroad but also from their village to the capital city. Despite a great boom in the use of social networks, our respondents showed no interest in having their shopping delivered home. This fact can be ascribed mainly to exorbitant unemployment (estimated at 97\% - statistically exact figures for the region are not available). Shopping itself is one of joyous social occasions where people meet and talk, listen to music, dance, and the like... The above-mentioned widespread popularity of visiting social networks and watching TV broadcasting, both full of advertisements, influence the process of deciding about what to buy - the advertised goods are always best! The influence is even amplified when a product is promoted by a celebrated foreign singer, actor or another VIP. Globalization affects also social \& cultural life. Social networks then can be blamed for the loss of indigenous traditions and languages. Such languages are kept alive only thanks to the elderly - children are taught only the official, that is the English language. To give an example, let us mention some previously traditional tribes: Maasai people and Bushmen now put on their traditional costumes only to stage shows for tourists who return home convinced that the tribespeople dress and live in such a way all year round. Actually, in their everyday life the people follow what they perceive as the latest fashion that they know from TV. They have also departed from their natural traditions and behavior - hunting, cooking on open fire, etc. - and started to use modern things.

To give an example, let us mention some previously traditional tribes: Maasai people and Bushmen now put on their traditional costumes only to stage shows for tourists who return home convinced that the tribespeople dress and live in such a way all year round. Actually, in their everyday life the people follow what they perceive as the latest fashion that they know from TV. They have also departed from their natural traditions and behavior - hunting, cooking on open fire, etc. - and started to use modern things.

Benefits of globalization: growing volume of goods traded globally; speed and holistic character of the direct flows of investments (direct investments); economic growth of some previously developing countries and the development stimulation of others; growth of consumption; emergence of a homogenous middle class and professional elites in Asia and Latin America; emergence of newly politically organized supranational entities and/or the strengthening of older entities (European Union, NAFTA); the same applies to entities of regional and sub-regional character (Euroregions); emergence of what is known as the second modernity (or translocal culture), i.e. a culture that is open to global influences coming through mass media from outside, as opposed to the first modernity (national and/or nationally centripetal) which is encapsulated in itself,

Drawbacks of globalization unrestrained investment capital transferred in volumes several times greater than what would just reflect the volume of traded goods - this fact entails the risk of economic collapse, a phenomenon already several times experienced; growing inequality in access to the overall social progress - the access is gained only by persons better 
fitted for growth; despite globally growing consumption, $20 \%$ of the poorest world population remain unaffected by the consumption explosion; summarized globally, $20 \%$ of world population living in the highest-income countries spend $86 \%$ of overall expenses spent on consumption - in contrast, $20 \%$ of the poorest population spend just $1.3 \%$; unemployment observed in developing countries either increases or does not diminishes; globalization weakens the roles of nation states; countries governed by less strict environmental regulations and those blessed with substantial natural resources are targeted by so-called cultural invasion; media and information technologies produce what is termed the second environment and this environment then molds social relations [21].

\section{Conclusion}

The cultural globalization has expanded the intellectual horizons of people, but it can also be blamed for their loss of identity. Globalization should not become a cause for neglecting (1) effort to improve democracy, (2) more effective fight with corruption, and (3) the deterrence of organized crime. The effect that globalization may exert on gradual development of democracy in the least developed countries can be viewed from two angles: some people believe that globalization liberates economy and democratizes political regimes; their opponents maintain that globalization deteriorates the power that governments wield over the domestic market. The least developed countries can then become less competitive. Having considered the relevant literature and taken advantage of our practice, we believe that the key factor in fighting poverty and expediting economic growth is an effective and optimized system of government. In Africa, globalization has brought together diverse cultures and allowed the locals to think in broader terms. These achievements themselves can foster tolerance and promote gender equality. Unfortunately, globalization has also weakened the sense of identity (as observed primarily in traditional societies and communities). Despite the weakening, culture still gives the communities a feeling of dignity, continuity and safety - it also keeps them united. Communities, indispensable in African countries, often do the duty of a social safety net for both individuals and entire families. In many countries of Africa, particularly inside different ethnic groups, we have witnessed what could be called "cultural confusion" caused obviously by sudden social changes - these phenomena offer themselves as subjects for further cultural and social anthropology researches.

The theme and research of this paper "Globalization - its influences \& impacts on specific regions of Africa“" was realized from the projects: NAKI II Právní, historické a společenskovědní aspekty nových a tradičních menšin v České republice.

\section{References}

1. T. Halík. Úvahy na prahu tisíciletí. Nakladatelství Lidovénoviny. (2011)

2. G. Therbron. Globalizations: Dimensions, Historical Waves, Regional Effects, Normative Governance. Sage Journals, 15, 151-179, (2011)

3. G. Therbron. Globalizations: Dimensions, Historical Waves, Regional Effects, Normative Governance. Sage Journals, 15, 151-179, (2011)

4. H. V. Perlmutter. The Tortuous Evolution of Multinational Enterprises, Columbia Journal of World Business, 1, 9-18. (1969).

5. M. Macik-Frey., J. C. Quick, D. L. Nelson, Advances in Occupational Health: From a Stressful Beginning to a Positive Future. Journal of Management, 33(6), 809-840 (2007) 
6. V. Lehdonvirta, Kässi, O., Hjorth, I., Barnard, H., \& Graham, M. The Global Platform Economy: A New Offshoring Institution Enabling Emerging-Economy Microproviders. Journal of Management, 45(2), 567-599 (2019)

7. S. Shane, S., Venkataraman, S., \& MacMillan, I. Cultural Differences in Innovation Championing Strategies. Journal of Management, 21(5), 931-952 (1995)

8. M. M. Keupp, Gassmann, O. The Past and the Future of International Entrepreneurship: A Review and Suggestions for Developing the Field. Journal of Management, 35(3), 600-633 (2009)

9. M. Stelios, Papaioannou, E. National Institutions and Subnational Development in Africa, The Quarterly Journal of Economics, 129, 1, 151-213 (2014)

10. Ch. Shaohua, Ravallion, M. The Developing World is Poorer than We Thought, But No Less Successful in the Fight Against Poverty, The Quarterly Journal of Economics, 125, 4, 1577-1625 (2010)

11. V. F. Caicedo, The Mission: Human Capital Transmission, Economic Persistence, and Culture in South America, The Quarterly Journal of Economics, 134, 1, 507-556 (2019)

12. A. Kowalska, J. Kovarnik, J., Hamplova, E. Prazak, P. The Selected Topics for Comparison in Visegrad Four Countries. Economies, 6, 3 (2018)

13. A. Seberíni. Routine expectations of social work. In Późna dorostość - doświadczenia, problemy, wsparcie spoteczne i edukacyjne, 213-221 (2014)

14. Lere, IshakuBitrus, Globalization and Development. TheImpact on Africa; A PoliticalEconomyApproach. OIDA International JournalofSustainableDevelopment, 7, 9 (2014)

15. V. Khapoya. TheAfricanexperience: anintroduction. 4th ed. UpperSaddle River, N.J.: Pearson (2013)

16. L. Plocha, M. Ch. B. Blamcherd, R. O'rourke, R. Ch. MasonPiracyoffthe Horn ofAfrica [online]. 2011 Available at: http://www.fas.org/sgp/crs/row/R40528.pdf (2011)

17. C. Postelnicu, V. Dinu, D. C.Dabija. Economicdeglobalization - fromhypothesis to reality. E+M Ekonomie a Management, 18, 6-3, 18, 4-14.

18. T. Risse, S. Ropp K. Sikkink. ThePowerofHumanRights: International Norms and DomesticChange. Cambridge (1999).

19. Rodrik. Has globalizationgonetoo far? Washington, D.C: Institute for International Economics (1997)

20. A. E. Goldman, Thegroupdepth interview. Journalof Marketing, 26, 52-61. (1962)

21. V. Mezřický. Globalizace a globálni problémy.Univerzita Karlova. (2006) 